\title{
EFFECT OF PURPLE SWEET POTATO EXTRACT ON GLUTATHIONE PEROXIDASE IN HOUSE MICE LIVER AFTER MAXIMUM PHYSICAL EXERCISE
}

\author{
Ayu Elvana1), Herla Rusmarilin²), Ramlan Silaban3), Rika Nailuvar Sinaga4) \\ 1) School of Health Sciences (STIKes) Siti Hajar, Medan, Indonesia \\ 2) Faculty of Agriculture, North Sumatra University \\ 3) Faculty of Mathematics and Science, Medan State University \\ 4) Faculty of Sport Science, Medan State University
}

\begin{abstract}
BACKGROUND: Physical exercise can improve antioxidant defense system of an organism, but this process may take a long time. Heavy exercise may disrupt oxidant-antioxidant balance. Low glutathione peroxidase is a biomarker for free radicals. Plant purple sweet potato (Ipomoea batatas L.) contains high anthocyanin that may act as an antioxidant. This study aimed to determine the effect of purple sweet potato extract on the activity of glutathione peroxidase in the liver of mice (Mus Musculus) treated with maximum physical exercise (MPE).

SUBJECT AND METHODS: This was a randomized controlled trial using a sample of 24 white DD Webster strain male mice. This sample of mice was randomized into 6 groups: P1-control, P2-MPE, P3-0.5 ml purple sweet potato, $\mathrm{P} 4-\mathrm{MPE}+0.5 \mathrm{ml}$ purple sweet potato, $\mathrm{P} 5-\mathrm{MPE}+1 \mathrm{ml}$ purple sweet potato, and $\mathrm{P} 6-\mathrm{MPE}+1.5 \mathrm{ml}$ purple sweet potato. The purple sweet potatoes were given for 14 days. Difference in means of glutathione peroxidase among the study groups was tested by Kruskal-Wallis.

RESULTS: After 14 days of intervention, the level of glutathione peroxidase (mean $\pm \mathrm{SD}$ in $\mathrm{mU} / \mathrm{ml}$ ) among the study groups were as

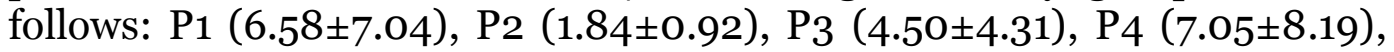
$\mathrm{P} 5$ (19.39 \pm 7.06$), \mathrm{P} 6(3.03 \pm 1.98)$. The highest level of glutathione peroxidase was attained in group $\mathrm{P}_{5}$ with moderate dose $(1 \mathrm{ml})$ of purple sweet potato extract.
\end{abstract}

CONCLUSION: Moderate dose $(1 \mathrm{ml})$ of purple sweet potato extract can effectively increase glutathione peroxidase enzyme in mice.

Keywords: maximum physical exercise, free radical, purple sweet potato, anthocyanin, glutathione peroxidase 